UDC 330.341

\title{
POTENTIAL OF INFORMATION TECHNOLOGIES OF UKRAINE IN THE WORLD IT MARKET
}

DOI 10.30838/ P.ES.2224.290818.74.210

\section{Stavytska A.

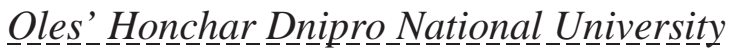

As a result of the deployment of globalization processes and the dissemination of informatization of society, the new information technologies arise. Accordingly, this creates new opportunities for the development of the domestic information technology market and the use of information technology and IT products by Ukrainian enterprises in the context of integration into the global information society, which determines the need to analyze the current potential of the Ukrainian IT market. The article reveals positive and negative factors of the development of the information technology market in Ukraine. The trends of change of the Network Readiness Index of Ukraine have been determined; the author presents the largest players of the national IT market of Ukraine, namely, transnational IT companies that form the potential of the Ukrainian information sector. The prospects of expanding the information technology potential of Ukraine in order to intensify participation in the world IT market have been explained, from which the conclusion is made of the need to strengthen the role of the state as a coordinating mechanism. The practical significance of the work forms the need for continuous monitoring of trends of Ukrainian IT market in order to find effective tools for protecting its participants from cybercrime.

Keywords: potential, trends, National Program, information technologies, national IT market, IT services, development, IT products, Internet users.

УДК 330.341

\section{ПОТЕНЦІАЛ ІНФОРМАЦЙНИХ ТЕХНОЛОГІЙ УКРАЇНИ В УМОВАХ СВІТОВОГО ІТ РИНКУ}

DOI 10.30838/ P.ES.2224.290818.74.210

Ставицька А. В.

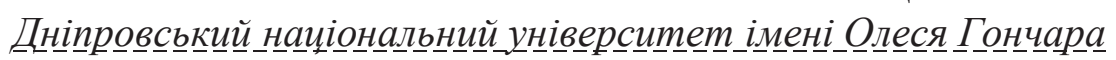

В результаті розгортання процесів глобалізації та поширення інформатизації суспільства виникають нові інформаційні технології. Відповідно, це створює нові можливості для розвитку вітчизняного IT ринку та використання інформаційних технологій та IT продуктів українськими підприємствами в контексті інтеграції в глобальне інформаційне суспільство, що визначає необхідність аналізу потенціалу IT ринку України. Стаття розкриває позитивні та негативні фактори розвитку ринку інформаційних технологій України. Автором визначено тенденції зміни Індексу мережевої готовності України; представлено найбільших гравців національного IT ринку України, а саме - транснаціональні IT компанії, які формують потенціал інформаційної сфери України. Також автором з’ясовано

(C) Ставицька А. В., 2018 
перспективи розширення потенціалу інформаційних технологій України задля активізації участі на світовому IT ринку, 3 чого зроблено висновок про необхідність посилення ролі держави як координуючого механізму. Практичне значенні роботи формує необхідність постійного моніторингу тенденцій розвитку ринку інформаційних технологій України задля пошуку ефективних інструментів захисту його учасників від кіберзлочинності.

Ключові слова: потенціал, тенденції, національна програма, інформаційні технології, національний IT ринок, IT послуги, розвиток, IT продукти, користувачі Інтернету.

Actuality of issue. Intellectualization and informatization of the national economy of Ukraine in the conditions of globalization require the implementation of integrated and balanced changes that shape the potential of information technology of our state. Today's information technologies are the starting point for production, distribution, exchange and consumption, which actualizes the need to conduct research on the potential of Ukraine's information technology in the world IT market. Identification of the potential of Ukraine's information technologies in the world IT market allows to identify the positive and negative factors of the development of the national IT market, to investigate the state of cyber security and to find out ways of minimizing cybercrime. The state of the national economy influences on Ukrainian information technology market. An important aspect is also taking into account the coordinating role of the state in identifying further perspectives of the national potential of information technologies.

Analysis of the previous researches. Research of the potential of the Ukrainian information technology market was carried out by Ukrainian scientists: Dubov D.V., Hanushchak-Efimenko L. M., Kondrat O.V., Machuha R.I., Meshko N.P., Chornous G.O., Yakubovskiy S.A. and others. The official statistical publications of the State Statistics Service of Ukraine, official annual reports of organizations and companies were the basis for statistical analysis. But the unresolved part of the problem of studying the state of the IT market of Ukraine is limited access to official statistics of Ukrainian enterprises, in particular, according to their economic activity, which limits the possibility of more detailed provision of prospects and forecasts.

The purpose of this article is to determine of the potential of information technologies of Ukraine in the world IT market.

Statement of the main research. In modern society, processes of globalization change the importance of resources in economic life, providing the signs of value to such sources as information and knowledge. For Ukraine, 
which takes an active part in integrating into the global information society, such processes allow to expand opportunities for access to national and world information resources, improvement of conditions and quality of people life.

One of the most acute problems of the present, which requires a scientific solution, is to overcome the gap in levels of economic development among countries of the world through the intensification of the use of information technology. Intensifying the use of IT in Ukraine will gradually reduce the differences in the levels of economic development of individual sectors and sectors of the national economy.

In Ukraine, at the legislative level in 1998, the National Program for Informatization was adopted [1]. This Program defines the general principles for forming a complex of interrelated separate tasks (projects) of informatization aimed at implementation of the state policy and priority directions of creating the modern information infrastructure of Ukraine. Due to the concentration and rational use of financial, logistical and other resources, the industrial and scientific and technical potential of the state, as well as the coordination of activities of state bodies, local authorities, enterprises, institutions, organizations of all forms of ownership and citizens in the field of information, there will be positive developments.

Since this Program is approved by the Law, it defines and delimits such concepts as information service, information technology, information product and information resource. According to the Law [1], information technology is a focused, organized set of information processes using computer facilities that provide high speed data processing, rapid information search, dispersal of data, access to sources of information, regardless of where they are located.

An important component of the formation of the modern information society potential in Ukraine in the context of globalization is the use of opportunities of modern information technologies to create a powerful knowledge base for the development of goods and services, contributing to a sustainable and efficient economic development of the country.

According to the State Statistics Service of Ukraine [2], the majority of Ukrainian enterprises (94\%) which have access to the Internet use it for banking and financial services; for information (56\% of enterprises); execution of administrative procedures (declaration, registration, request for permission (52.5\% of enterprises). Almost every fifth company, using the website's capabilities, makes online payments and posts public vacancy announcements, or provides an opportunity to apply for vacant positions online. 
Ukraine's information technology market has a great potential due to the existing internal positive factors of development:

- territorial proximity to European customers;

- the leading software makers of European countries are located in Ukraine;

- time zone similar to European customers;

- Ukraine is one of the leaders among European countries in terms of production software;

- large number of educated and highly skilled specialists;

- high quality IT products (software segment) and IT services;

- the cost of IT products and IT services is slightly lower compared to European developers [3].

The national information technology market provides 3\% of Ukraine's GDP; the number of employees in the IT sector amounts to 306.3 thousand people, which is almost $3.5 \%$ of the total number of employed [2]. The capacity of IT outsourcing in Ukraine and the software production market is more than 1 billion. US per year.

At the same time, the negative internal factors of the development of the information technology market in Ukraine are:

- political crisis and military conflict with Russia;

- low investment attractiveness of the economic environment;

- compared to European countries, the number of Ukrainian Internet users is lower;

- shadowing of financial transactions and labor in the IT market;

- high level of "piracy" in the IT market [3].

After the crash of dotcoms in 2000, the World Bank first spotted the IT industry in Ukraine and included the country in the IT export statistics. Three years later, the first Ukrainian study of the status of the IT industry was completed and the professional association "IT of Ukraine" was founded.

The national IT market in Ukraine is developing very quickly and has a worldwide recognition. Ukrainian IT companies are part of Global Outsourcing 100 list. Ukrainian e-commerce market is estimated at more than 2 billion USA dollars. More than 100 multinational research and development centers from various industries, including telecom operators, software, gaming and e-commerce, are already in place in Ukraine [10].

The main Ukrainian consumers of IT products: financial sector, telecommunications, trade, industry, public administration. Now in Ukraine 
there are about 4 thousand IT companies, and the total number of IT specialists in the information technology market is 40-50 thousand people [5].

In the global economy there are processes of commercialization of information technologies. That is why, due to the active participation in this process of transnational corporations, their re-orientation to the market situation has taken place. Today, more than $80 \%$ of the information technology market is controlled by multinational corporations, which annually invest in the production of new high-tech products, allocate considerable funds for the development of global marketing strategies and the development of new markets by IT means.

The largest players in the IT outsourcing market are mainly represented by affiliates of international companies, as well as large companies with a central office in Ukraine. These companies are typically export oriented, with most of their clients in the US and often in Western Europe. In particular, these are foreign Global Logic, EPAM Systems (USA), Ciklum (Denmark), Soft Serve, Infopulse Ukraine (Ukraine) [6].

According to the website "Internet Business in Ukraine" [7], there are six large multinational IT companies known all over the world and have different representations and affiliates from different countries:

- the largest IT company Paymentwall, founded in 2010, has an annual turnover of 50 million dollars. USA. The services of this company are used by most famous TNCs of the world. Offices of the company are located in 10 countries of the world;

- not less known is Grammarly Ukrainian IT company, which has more than 7 million. Users, 4.1 million signatories to Facebook and contracts with 550 leading world universities;

- Terrasoft is primarily known as the manufacturer of CRM and Service Desk systems. Originally, Terrasoft CRM was designed to work in medium and small companies, but eventually the company focused on creating systems for large corporations;

- Invisible CRM is called the largest food company in Ukraine. The company is engaged in developing technology as a product, licensing it and selling it to the global vendors Microsoft and Oracle. The estimated turnover of the company for 2012 amounted to more than 30 million UAH;

- the IT company is Deposit Photos, an annual revenue of 6 million USA dollars. Deposit Photos is an international photo bank, which is an intermediary between image authors and their buyers. Today, the service offers more than 
25 million photos, vector images and royalty-free videos. The company provides services to clients from all over the world, providing them with support in 14 languages;

- IT company Jooble, which appeared in 2006, is a kind of Google for job search. Resource assignment - aggregate job vacancy offers, billboards, company sites, and provide users with access through a single interface.

Taking into account the relevant tendencies, the Ukrainian IT sector and the IT market are characterized mainly by the position of the supplier for the export of not the complete final product, but only its elements, that is, the original "raw materials". Also, the big problem of the information technology market in Ukraine is a small support from the state. In most countries, the government supports the IT industry to provide additional impetus to the industry and make it attractive to potential clients and investors through benefits and social taxes. Introduced in 2014-2015, the limitation of the withdrawal of profits from investment activities from Ukraine is also an unfavorable factor affecting the IT market in Ukraine.

Although over the past five years, Ukraine has shown positive dynamics of the positions in the Readiness Index, but the change in the Index values is primarily due to changes in the methodology and is not supported by fundamental changes in the development of information technology in the state (Figure 1). The rating index varies from the largest remote value to the advanced position towards the decrease of the indicator.

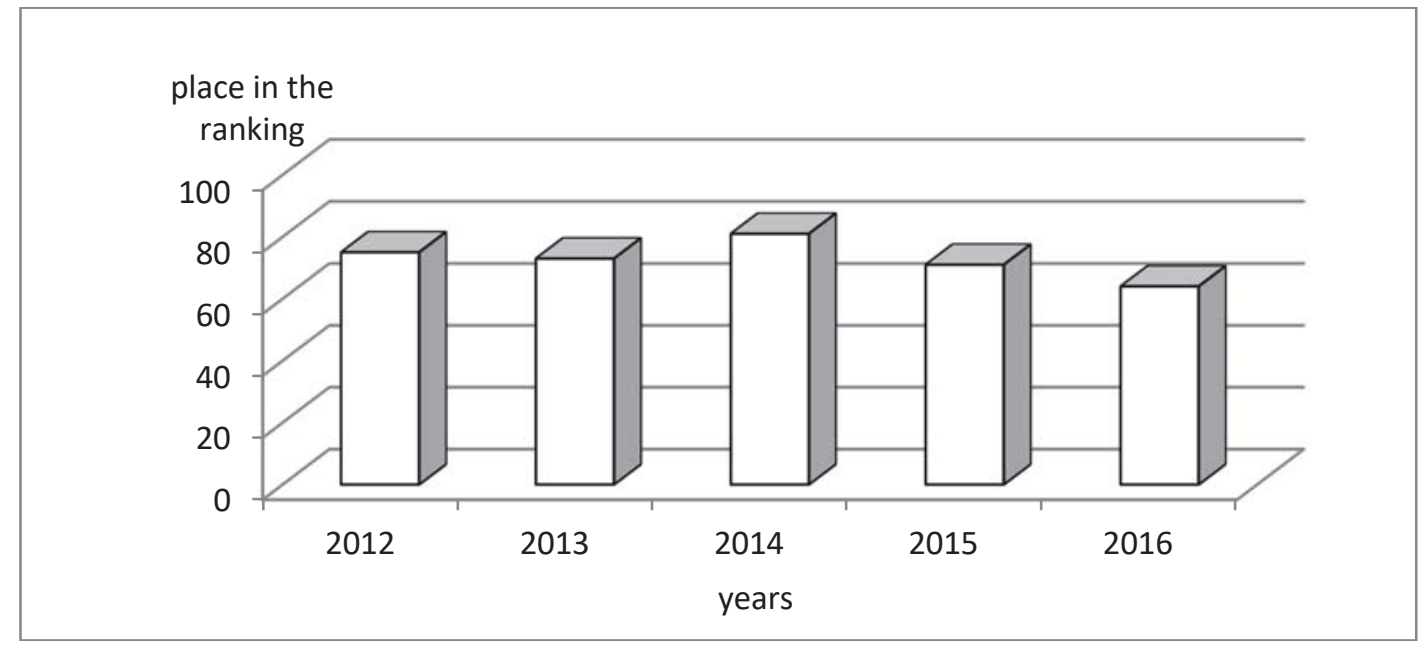

Fig. 1. Dynamics of change of the Network Readiness Index of Ukraine during 2012-2016 years

Source: compiled by the author according to [8]

This rating points to the loss of Ukraine's position as a technologically oriented country and its increasing information vulnerability, and hence 
dependence on world leaders in the global IT market. In 2016, its rating is 64, which raised Ukraine by only 7 steps compared to 2015 . The reason for the rather low position of Ukraine in the world rating is, first of all, the lag behind the components that characterize the political and regulatory environment and the low level of use of IT by the government.

For 2014-2017, Ukraine remains the leader among the "free development" software in Central and Eastern Europe. Based on the research of Gartner, Ukraine is on the list of TOP-30 countries which software products are in high demand around the world. The high quality of software is traditionally based on the high qualification of IT professionals and the high degree of maturity of the IT community. The estimated volume of Ukrainian software development outsourcing market exceeded 1 billion. USA [9].

The main trends in the development of the IT market in Ukraine are $[10 ; 11 ; 12 ; 13 ; 14 ; 18]$ :

- growth of IT services export due to increased demand for outsourcing of computer equipment and support of network infrastructure;

- increased consumption of IT outsourcing services in the domestic market;

- growth of the number of suppliers of services with the participation of foreign capital or partly financed by foreign capital;

- growth of the volume of auxiliary IT services (IT infrastructure support).

In Ukraine, the overall ease of doing business has 81 position, then, as a consequence, the introduction of foreign information technology is a complex process, and not always attractive for foreign partners. For the Ukrainian economy, the information technology market is very important and therefore needs help from a foreign investor. But statistics, on the contrary, indicate that there are obstacles to investing in the IT sector of Ukraine.

Professor N.P. Meshko, when developing the forecast of the volume of the IT market of Ukraine, noted that in the future, the development of the information technology market will be significantly influenced by factors such as foreign direct investment, export of services, GDP and average salary, high uncertainty of political and economic the situation in the country [13].

Modern Ukrainian IT users, namely companies, organizations and individuals, want to have a quality product with minimal resources: less hardware and software, less system maintenance costs. At the same time reducing costs - the main factor in the penetration of cloud technologies. 
According to the results of the survey of companies-system integrators, while $16 \%$ of business users use such technologies in Ukraine, $17 \%$ of which are banks, $20 \%$ - distribution, $17 \%$ - industry, $13 \%$ - public sector [15].

The relatively high level of remuneration shows the dynamism of the development of the IT industry, since wages are shaped primarily by the profitability of the industry and its profitability. Few other industries in Ukraine are able to boast such wages. For example, EU experts state that "... the minimum wage should be 2-2.5 living wages, and in this case it is in most countries of the world is $35-40 \%$ of the average" [16]. Therefore, according to this indicator, the Ukrainian IT industry has begun to bring confidence.

Ukraine ranks fourth in the world by the number of certified IT specialists (after the USA, India, Russia), is included in the top 30 locations for the transfer of software development orders. This shows the huge growth potential of the information technology industry and the significant role of Ukraine as a supplier of IT products in the global market.

The key advantages of the software development industry are that large investments in fixed assets are not required to increase production, since the main asset of the IT industry is the human factor (programmers, IT specialists, etc.).

In general, Ukraine has formed the foundations of the information society, but in this context, Ukraine, according to different IT development rankings, is roughly 60th among 150-190 countries and far behind most developed countries. This requires the creation and implementation of a national policy to find a decent place in the global IT market.

In general, it was formed the foundations of the information society in Ukraine, but in this context, according to different IT development ratings Ukraine is roughly 60th among 150-190 countries and is significantly behind the majority of developed countries. This situation requires the creation and implementation of a national policy to find a decent place in the global IT market for Ukraine [9].

Positive prospects for Ukraine are defined for the following purposes of the national information policy: creating a national information infrastructure; encourage access to IT and its use by government agencies, private sector and civil society; development of human resources; creation of a system of economic stimulation and effective institutional structure of the national innovation system. 
For Ukraine, which has no estimates of the national IT market at all, and in which most of the participants in this market are in the shadows. The definition of the extent to which IT segments of the market are covered by individual participants is expedient and simplified.

Intellectualization and informatization of the national economy of Ukraine in the conditions of globalization require the implementation of integrated and balanced changes in: legal, scientific and technical, educational, budget, financial and credit, industrial, distributive, foreign economic, demographic, migration, social, insurance, investment, housing and communal, information, innovation, socio-cultural and other policies [17].

In the context of the globalization of the world information technology market, the formation of the competitiveness of Ukrainian IT products will continue through various forms of cooperation: from the formation of integrational associations to the creation of coalitions, alliances and other forms of "exceptional relations" between market players. Such relationships create new market structures and improve its business environment. Sharing the potential of market participants through a broad basis of accumulated competencies, sharing costs and risks between contractors, building a common architecture for the implementation of individual elements of the market offer enables market players to form a high level of competitiveness.

Recent cyberattacks, which have affected the IT image of Ukraine, require continuous monitoring and regulation of evolving cyber threats in the IT market. In June 2017, the first in Ukraine in Kyiv was a world-wide event Global Cybersecurity Summit 2017 (GSC17). It is a unique platform where hundreds of experts and top level officials are concentrated in order to develop practical solutions to current trends in cybersecurity. In the framework of this event, a consolidation of public and private efforts in the field of cybersecurity has been introduced in the long run. Representatives of government, business, nonprofit organizations, individuals and academics will be able to get acquainted with best practices, latest advances and innovations in security systems in areas such as politics and governance, Internet matters, and industrial asset management systems. Secure cyberspace for Ukraine is a strategic direction of international cooperation in the IT field and the safe representation of Ukrainian IT products on the world market.

But under such circumstances, the acute problem in the Ukrainian information technology market will remain the current mechanism of 
protection and sanctions for violating the legislation in the IT field. The lack of transparency is a problem of the national Ukraine market of information technologies. And, therefore, it requires the improvement of national regulatory mechanisms in the IT field by approving changes to existing laws, adopting new laws. It is also necessary to create a controlling body with a full arsenal of functions and tools for sanctions for violations of IT law. And the improvement of the national informatization policy, information security and protection of intellectual property that will expand the potential of Ukraine's information technology.

Conclusions. The author's research of priority directions and the potential of Ukraine IT within the global IT market has shown the need for the development and application of effective mechanisms: ensuring the implementation of constitutional norms and the realization of citizens' rights; optimization and adaptation of legislation; ensuring national economic security; protection and effective property management; development of human potential and capital of citizens; regulation of market dysfunctions; formation of adaptive education; activization of scientific activity in priority areas; stimulating the spread of new technologies in production. In the near future, the state of the national economy will affect the Ukrainian information technology market. Strategic directions of development of the national Ukrainian IT market should become logically consistent with the warld tendencies.

\section{REFERENCES:}

1. Закон України «Про Національну програму інформатизації» від 04.02.1998 № 74/98BP (із змінами та доповненнями). [Електронний ресурс]. - Режим доступу: http:// zakon4.rada.gov.ua/laws/show/74/98-\%D0\%B2\%D1\%80. - Заголовок з екрана.

2. Ukrstat.org - публікація документів Державної Служби Статистики України. [Електронний ресурс]. - Режим доступу: https://ukrstat.org/uk/druk/publicat/kat_u/ publinform_u.htm. - Заголовок з екрана.

3. Макинтайр Д. Главные конкуренты Украины на мировом ИТ-рынке - Польша и Латинская Америка - эксперт. - Режим доступа: https://delo.ua/tech/chchchch324285/. - Загл. с экрана.

4. Yakubovskiy S. A. Development of the world market of information technologies in the conditions of transnationalization of international business / S.A. Yakubovskiy, Y.A. Kavetskyi // Вісник ОНУ імені I.I. Мечникова. - 2018. - Т.23 Вип. 2 (67). - c. 12-15. 
5. Пан Л. В. Способи покращення захисту інформації на ринку інформаційних продуктів та послуг в Україні. - Режим доступу : http://ekmair.ukma.edu.ua/bitstream /handle/123456789/1122/Pan_Sposoby.pdf;jsessionid=28CBA4F56C1B4EA9DF4A3A20 AA871A83?sequence=1. - Назва з екрану.

6. Association of Ukrainian IT Outsourcing companies. - Access mode: http://hi-tech.org.ua. - Title from screen.

7. Ворона Т. 6 всесвітньо відомих IT-компаній, створених в Україні. Сайт «Інтернетбізнес в Україні». [Електронний ресурс]. - Режим доступу: http://ain.ua/545000. Назва з екрану.

8. The Global Information Technology Report 2016. - Access mode : https://www.weforum.org/reports/the-global-information-technology-report-2016. - Title from screen.

9. Exploring Ukraine IT-outsourcing industry. - Access mode: www.hi-tech.org.ua. - Title from screen.

10. Ганущак-Сфіменко Л. М. Особливості розвитку підприємництва в IT-сфері України / Л. М. Ганущак-Сфіменко // Актуальні проблеми економіки. - 2016. - №10 (184). C. $55-67$.

11. Мачуга Р. I. Сучасний стан ринку інформаційно-комунікаційних технологій України / Р. I. Мачуга, О. С. Борух // Східна Свропа: економіка, бізнес та управління. - 2016. - № 3. - C. 266 - 270.

12. Мешко Н. П. Інноваційний розвиток країн світової економіки в умовах глобалізації: моногр. / Н. П. Мешко. - Донецьк : Юго-Восток, 2008. - 345 с.

13. Мешко Н. П. Перспективи розвитку сфери ІТ як провідної інноваційної галузі України / Н. П. Мешко, М. К. Костюченко // Вісник Дніпропетровського університету. Серія «Менеджмент інновацій». - 2015. Випуск 4. - С. 71 - 77.

14. Кіндрат О.В. Сучасні інформаційні технології - найперспективніша інвестиція у розвиток підприємства / О.В. Кіндрат // Науковий вісник ЛНУВМБТ імені С.3. Гжицького. - 2016,. - т. 18 № 2 (69). - с. 72-74.

15. Чорноус Г. О. Стан і перспективи впровадження новітніх інформаційних технологій в Україні / Г. О. Чорноус // Економіка та держава. - 2014. - №1. - С. 13 - 18.

16. Осовий Г. В. Питання реформи оплати праці в Україні / Г. В. Осовий // Праця і Закон. - 2015. - № 7. - C. 6 - 19.

17. Дубов Д. В. Широкосмуговий доступ до мережі інтернет як важлива передумова інноваційного розвитку України: аналіт. доп. / Д. В. Дубов, М. А. Ожеван. - К. : НІСД, 2013. - $108 \mathrm{c}$.

18. Ставицька А.В. Заходи подолання глобальних та регіональних деструкцій світового ринку інформаційних технологій. Східна Свропа: економіка, бізнес та управління. 2017. Випуск 6(11). С. 15-18. URL: http://www.easterneuropeebm.in.ua/journal/11_2017/11_2017.pdf. 